\title{
Multivariate Regression Analyses of Yield Associated Traits in Rapeseed (Brassica napus L.) Genotypes
}

\author{
Valiollah Rameeh \\ Agriculture and Natural Resources Research Center of Mazandaran, Sari, Iran \\ Correspondence should be addressed to Valiollah Rameeh; vrameeh@yahoo.com
}

Received 5 April 2014; Revised 26 July 2014; Accepted 14 August 2014; Published 24 August 2014

Academic Editor: Nnadozie Oraguzie

Copyright (C) 2014 Valiollah Rameeh. This is an open access article distributed under the Creative Commons Attribution License, which permits unrestricted use, distribution, and reproduction in any medium, provided the original work is properly cited.

\begin{abstract}
The efficiency of a breeding program depends mainly on the direction of the correlation between yield and its components and the relative importance of each component involved in contributing to seed yield. The interrelationships of nine quantitative traits in 28 genotypes of spring oilseed rape (days to flowering, days to end of flowering, duration of flowering, days to maturity, pods per main raceme, pods length and pods per plant, and seed yield) were computed. Significant genotypic effects were found for phenological traits, yield components, and seed yield, indicating significant genetic differences among the genotypes. High broad sense heritability was estimated for phenological traits, seeds per pod, and seed yield, signifying high selection gain for improving these traits. Path coefficient analysis revealed that days to flowering and number of pods per plant had the highest direct effects on seed yield. Duration of flowering, number of branches, pods on main raceme, pods per plant, and seed yield had high genetic coefficient of variation. The results of factor analysis showed three factors including factor 1 (phenological traits), factor 2 (primary yield components), and factor 3 (secondary yield components). The results of stepwise regression analysis revealed that pods per plant, number of branches, and duration of flowering had considerable effects on seed yield.
\end{abstract}

\section{Introduction}

Improvement of seed yield in canola (Brassica napus L.) has been the main objective of canola breeders for many years $[1,2]$. Seed yield is a quantitative trait, which is principally influenced by the environment and consequently has a low heritability $[3,4]$. As a result, the response to direct selection for seed yield may be unpredictable, unless there is good control of environmental variation. Plant breeders are seldom interested in a single trait and therefore, there is the need to examine the relationships among different traits, especially between seed yield and other traits. As the number of independent variables influencing a particular dependent variable increases, a certain amount of interdependence is expected. In such situations, correlations may be inadequate to explain the associations in a way that will enable breeders to decide on a direct or indirect selection strategy [5]. The multivariate analyses, particularly factor and cluster analyses, are utilized for evaluation of a large number of accessions for different traits in a germplasm collection. Cluster analysis assigns genotypes into qualitative homogenous groups based on response similarities and also assists in classifying genotypes. The method produces a dendrogram showing successive fusion of individuals. Greater heterotic effect is generated when clusters are divergent. Genetic diversity among the Brassica genotypes has been assessed by Choudhary and Joshi [6] using cluster analysis. The morphological characters, namely, days to flowering, plant height, secondary branches per plant, and 1000-seed weight, had a major contribution to genetic divergence $[7,8]$. Determination of correlation coefficients is an important statistical procedure to evaluate breeding programs for high yield as well as to examine direct and indirect contributions to yield variables [9-13].

The main applications of factor analytic techniques are to reduce the number of variables and to detect structure in the relationship between variables [14]. In plant breeding factor analysis is mainly applied as structure detection method, and sometimes it can be used as index selection for improving more than one trait. Factor analysis was used to determine structural factors related to growth trait and yield components and also to detect factors relating to environmental stress including drought resistance in B. napus [15]. 
The objectives of the present study were to estimate the genetic coefficient of variation, broad sense heritability, and the relationship among yield associated traits for improving seed yield in spring type rapeseed advanced lines.

\section{Materials and Methods}

The material under study consisted of 28 rapeseed ( $B$. napus L.) genotypes which were selected based on different agronomic characters. The genotypes were planted in a randomized complete block design with three replications at Baykola Agriculture Research Station, located in Neka, Iran $\left(53^{\circ} 13^{\prime} \mathrm{E}\right.$ longitude and $36^{\circ} 43^{\prime} \mathrm{N}$ latitude, $15 \mathrm{~m}$ above sea level) during 2012-13. The plots consisted of four rows $5 \mathrm{~m}$ long and $30 \mathrm{~cm}$ apart. The distance between plants on each row was $5 \mathrm{~cm}$ resulting in approximately 400 plants per plot, which were sufficient for statistical analysis. Crop management including land preparation, crop rotation, fertilizer, and weed control followed standard practices in the local area. All plant protection measures were adopted to make the crop free from insects. Phenological traits including days to flowering, days to end of flowering, duration of flowering, and days to maturity were determined based on phenological stages of the genotypes in each plot. Pods per main raceme, pods length, and pods per plant were recorded using 10 randomly selected plants in each plot. Seed yield of two middle rows of each plot was adjusted to $\mathrm{kg} / \mathrm{ha}$.

Variance components were estimated from the mean squares (MS) in the analysis of variance [16]. The components of variance including error variance (VE), genotypic variance (VG), and phenotypic variance (VP) were estimated according to the following formula:

$$
\begin{gathered}
\mathrm{VE}=\mathrm{MSE}, \\
\mathrm{VG}=\frac{(\mathrm{MSG}-\mathrm{MSE})}{r}, \\
\mathrm{VP}=\mathrm{VG}+\mathrm{VE} .
\end{gathered}
$$

Broad sense heritability $\left(h^{2}\right)$ was estimated according to Khan et al. [17] as $h^{2}=$ VG/VE. The coefficient of variation was estimated as $\mathrm{CV}=(\sqrt{ } \mathrm{VG}) / \mu$ where $\mu$ is the mean of genotypes for each trait.

Pearson's correlation coefficients between the traits, path coefficient analysis, and factor analysis based on Varimax rotation matrix were done on the data. Principal components method analysis was used to extract factorial load of matrix and also to estimate the number of factors $[14,18]$. The factors which had a root bigger than one were selected and were used to build the factorial coefficients matrix. All the calculations were performed using MS-Excel and SAS software version 9 [19].

\section{Results and Discussions}

3.1. Analysis of Variance. Significant mean square of genotypes were determined for the traits including days to flowering, duration of flowering, days to maturity, number of branches, pods per main raceme, pods per plant, seeds per pod, and seed yield indicating significant genetic variation for these traits (Table 1). Generally these results are similar to those reported by Aytaç and Kinaci [8] and Sabaghnia et al. [20]. Broad sense heritability estimates ranged from 0.12 to 0.98 for plant height and days to flowering, respectively. High values of broad sense heritability estimates for the phenological traits, seeds per pod, and seed yield indicate that selection gain for improving these traits will be high. Aytac et al. [3] also reported high broad sense heritability estimates for yield components. Genetic coefficient of variation, an indicator of the genetic diversity of the genotypes, varied from 18.7 to 26.8 for days to maturity and seed yield, respectively (Table 2). A high value for genetic variation was detected for duration of flowering, pods per main raceme, pods per plant, and seed yield.

3.2. Genotypic Means. Days to flowering ranged from 79 to 119 days (Table 2). A significant positive correlation was detected between days to flowering and days to maturity (Table 3), which suggests that selection for this trait could be done for early maturity genotypes. The genotypes including genotype 3 (G3), G16, G18, G25, and G27 with low mean values would be preferred for improving days to flowering (Table 2). These genotypes had low mean values of days for maturity. In rapeseed, since flowering and seed formation occurred about the same time, genotypes showing high mean values for duration of flowering will be preferable. High mean value for duration of flowering suggests that the plant gets enough time and opportunity for seed formation, and genotypes G3, G8, G18, and G25 with high mean values would be considered suitable for improving this trait. For reducing pest damage and also facilitate second crop cultivation after rapeseed, early maturity would be an ideal trait for breeding B. napus L. and other related Brassica species. Plant height ranged from 150 to $181 \mathrm{~cm}$. For ideotype breeding of rapeseed, low mean value of plant height is favored, and genotypes G6, G10, G12, and G19 would be suitable parents for this trait. Number of branches varied from 3.2 to 5.6. Since pods per plant were found significantly correlated with seed yield, the genotypes including G5, G14, G15, G19, and G21 would be suitable for improving this trait. Sharma [14] reported that pods per plant, seeds per plant, and 1000-seed weight traits were positively correlated with seed yield. Khan et al. [17] also reported a positive significant correlation between seed yield and plant height, pods per plant, seeds per pod, and pod length. The genotypes G14, G19, G21, G22, G23, and G24 with high mean values for seed yield also had high mean values for some other yield components.

3.3. Multivariate Analyses. Path coefficient analysis revealed that days to flowering and number of pods per plant had the highest positive effects on seed yield but duration of flowering and pods on main raceme had a significant negative effect on seed yield (Table 4). Marjanović-Jeromela et al. [21] studied 30 rapeseed varieties and demonstrated that pods per plant have the highest correlation with seed yield. Sheikh et al. [22] found high heritability estimates coupled with high genetic 
TABLE 1: Analyses of variance (ANOVA) and broad sense heritability estimates for the traits studied.

\begin{tabular}{|c|c|c|c|c|c|c|c|c|c|c|}
\hline \multirow[b]{2}{*}{ S.O.V } & \multirow[b]{2}{*}{ Df } & \multicolumn{9}{|c|}{ Mean squares } \\
\hline & & $\begin{array}{l}\text { Days to } \\
\text { flowering }\end{array}$ & $\begin{array}{l}\text { Duration } \\
\text { of } \\
\text { flowering }\end{array}$ & $\begin{array}{l}\text { Days to } \\
\text { maturity }\end{array}$ & $\begin{array}{l}\text { Plant } \\
\text { height }\end{array}$ & $\begin{array}{l}\text { Number of } \\
\text { branches }\end{array}$ & $\begin{array}{l}\text { Pods per } \\
\text { main } \\
\text { raceme }\end{array}$ & $\begin{array}{c}\text { Pods per } \\
\text { plant }\end{array}$ & $\begin{array}{l}\text { Seeds per } \\
\text { pod }\end{array}$ & Seed yield \\
\hline Replication & 2 & 2.3 & 16.9 & 3.0 & $938.9^{* *}$ & $7.72^{* *}$ & $1074^{* *}$ & $4005^{* *}$ & $216.3^{* *}$ & $973157^{*}$ \\
\hline Treatments & 27 & $161.1^{* *}$ & $219.9^{* *}$ & $51.6^{* *}$ & 156.1 & $1.03^{* *}$ & $98^{* *}$ & $561^{* *}$ & $16.0^{* *}$ & $810934^{* *}$ \\
\hline Error & 54 & 1.0 & 13.9 & 3.7 & 111.2 & 0.31 & 32.2 & 175.1 & 3.6 & 202709 \\
\hline $\begin{array}{l}\text { Broad sense } \\
\text { heritability }\end{array}$ & & 0.98 & 0.83 & 0.81 & 0.12 & 0.44 & 0.41 & 0.42 & 0.53 & 0.50 \\
\hline
\end{tabular}

SOV: source of variation.

${ }^{*, * *}$ Significant at $P<0.05$ and 0.01 , respectively.

TABLE 2: Mean comparison of the rapeseed genotypes for phenological traits, plant height, yield components, and seed yield.

\begin{tabular}{|c|c|c|c|c|c|c|c|c|c|}
\hline \multirow[b]{2}{*}{ Genotypes } & \multicolumn{9}{|c|}{ Traits } \\
\hline & $\begin{array}{l}\text { Days to } \\
\text { flowering }\end{array}$ & $\begin{array}{l}\text { Duration } \\
\text { of } \\
\text { flowering }\end{array}$ & $\begin{array}{l}\text { Days to } \\
\text { maturity }\end{array}$ & $\begin{array}{l}\text { Plant } \\
\text { height } \\
(\mathrm{cm})\end{array}$ & $\begin{array}{l}\text { Number of } \\
\text { branches }\end{array}$ & $\begin{array}{l}\text { Pods per } \\
\text { main } \\
\text { raceme }\end{array}$ & $\begin{array}{c}\text { Pods per } \\
\text { plant }\end{array}$ & $\begin{array}{l}\text { Seeds per } \\
\text { pod }\end{array}$ & $\begin{array}{c}\text { Seed yield } \\
(\mathrm{kg} / \mathrm{ha})\end{array}$ \\
\hline 1-Zar08-1 & 106 & 68 & 213 & 168 & 4.9 & 52 & 90 & 24 & 1952 \\
\hline 2-Zar01-3 & 106 & 64 & 213 & 176 & 4.9 & 41 & 72 & 22 & 2171 \\
\hline 3-Zar01-7 & 97 & 77 & 206 & 169 & 5.3 & 37 & 77 & 24 & 1893 \\
\hline 4-Zar01-8 & 104 & 61 & 206 & 160 & 4.6 & 47 & 72 & 23 & 2493 \\
\hline 5-22B01-14 & 108 & 61 & 212 & 163 & 5.1 & 38 & 110 & 24 & 3094 \\
\hline 6-22B01-15 & 111 & 54 & 211 & 154 & 4.3 & 31 & 87 & 18 & 3053 \\
\hline 7-22B01-16 & 109 & 65 & 211 & 168 & 3.9 & 39 & 102 & 19 & 3070 \\
\hline 8-Forn08-1 & 103 & 69 & 206 & 157 & 4.1 & 35 & 101 & 18 & 2194 \\
\hline 9-Forn01-7 & 106 & 68 & 208 & 165 & 4.3 & 36 & 70 & 19 & 1846 \\
\hline 10-Forn08 & 111 & 51 & 215 & 150 & 4.6 & 42 & 103 & 18 & 2704 \\
\hline 11-Mod04 & 108 & 68 & 213 & 160 & 3.8 & 34 & 71 & 19 & 2445 \\
\hline 12-Mod05 & 106 & 58 & 209 & 154 & 3.9 & 35 & 82 & 19 & 2484 \\
\hline 13-Mod06 & 117 & 51 & 214 & 181 & 5.6 & 47 & 81 & 22 & 2322 \\
\hline 14-Mod08 & 102 & 68 & 208 & 172 & 4.6 & 41 & 109 & 22 & 3113 \\
\hline 15-Mod09 & 104 & 68 & 212 & 158 & 5.2 & 34 & 107 & 22 & 2859 \\
\hline 16-Mod010 & 99 & 67 & 205 & 167 & 4.7 & 40 & 93 & 22 & 2274 \\
\hline 17-Mod011 & 103 & 67 & 209 & 163 & 5.1 & 34 & 83 & 19 & 2126 \\
\hline 18-Mod014 & 97 & 68 & 204 & 165 & 5.1 & 42 & 90 & 20 & 2195 \\
\hline 19-Mod01 & 109 & 50 & 210 & 152 & 4.6 & 32 & 107 & 21 & 3338 \\
\hline 20-Mod02 & 110 & 54 & 211 & 166 & 3.2 & 32 & 82 & 20 & 2830 \\
\hline 21-Zar01 & 110 & 54 & 212 & 163 & 4.8 & 40 & 114 & 20 & 3415 \\
\hline 22-Zar03 & 105 & 61 & 209 & 161 & 3.3 & 32 & 69 & 18 & 3104 \\
\hline 23-Zar025 & 103 & 61 & 213 & 167 & 4.5 & 43 & 102 & 21 & 3664 \\
\hline 24-Zar029 & 109 & 58 & 215 & 170 & 4.8 & 36 & 101 & 19 & 3582 \\
\hline 25-ОKР08 & 79 & 82 & 201 & 172 & 4.9 & 39 & 84 & 17 & 2152 \\
\hline 26-Sarigol & 119 & 49 & 221 & 171 & 4.4 & 45 & 100 & 19 & 2427 \\
\hline 27-Hyola401 & 97 & 60 & 210 & 167 & 5.2 & 47 & 91 & 26 & 2764 \\
\hline 28-RGS003 & 104 & 47 & 213 & 163 & 4.6 & 49 & 85 & 24 & 2487 \\
\hline $\operatorname{LSD}_{(\alpha=0.05)}$ & 0.94 & 3.52 & 1.81 & 9.94 & 0.52 & 5.35 & 12.48 & 1.79 & 424.48 \\
\hline $\operatorname{LSD}_{(\alpha=0.01)}$ & 1.25 & 4.68 & 2.41 & 13.22 & 0.70 & 7.12 & 16.59 & 2.38 & 564.56 \\
\hline $\begin{array}{l}\text { Genetic } \\
\text { coefficient of } \\
\text { variation }\end{array}$ & 19.8 & 23.0 & 18.7 & 19.1 & 22.4 & 23.4 & 23.8 & 21.6 & 26.8 \\
\hline
\end{tabular}


TABLE 3: Pearson's correlations between pairs of traits in rapeseed.

\begin{tabular}{|c|c|c|c|c|c|c|c|c|c|}
\hline Traits & $\begin{array}{l}\text { (1) Days to } \\
\text { flowering }\end{array}$ & $\begin{array}{c}(2) \\
\text { Duration } \\
\text { of } \\
\text { flowering }\end{array}$ & $\begin{array}{l}\text { (3) Days to } \\
\text { maturity }\end{array}$ & $\begin{array}{l}\text { (4) Plant } \\
\text { height }\end{array}$ & $\begin{array}{c}\text { (5) } \\
\text { Number of } \\
\text { branches }\end{array}$ & $\begin{array}{l}\text { (6) Pods } \\
\text { per main } \\
\text { raceme }\end{array}$ & $\begin{array}{l}\text { (7) Pods } \\
\text { per plant }\end{array}$ & $\begin{array}{l}\text { (8) Seeds } \\
\text { per pod }\end{array}$ & $\begin{array}{l}\text { (9) Seed } \\
\text { yield }\end{array}$ \\
\hline (1) Days to flowering & 1 & & & & & & & & \\
\hline (2) Duration of flowering & $-0.75^{* *}$ & 1 & & & & & & & \\
\hline (3) Days to maturity & $0.80^{* *}$ & $-0.68^{* *}$ & 1 & & & & & & \\
\hline (4) Plant height & -0.11 & 0.23 & 0.06 & 1 & & & & & \\
\hline (5) Number of branches & -0.21 & 0.16 & -0.04 & 0.35 & 1 & & & & \\
\hline (6) Pods per main raceme & -0.02 & -0.14 & 0.21 & $0.44^{*}$ & $0.46^{*}$ & 1 & & & \\
\hline (7) Pods per plant & 0.16 & -0.22 & 0.25 & -0.16 & 0.23 & 0.04 & 1 & & \\
\hline (8) Seeds per pod & -0.07 & -0.04 & 0.05 & 0.28 & $0.52^{* *}$ & $0.56^{* *}$ & 0.04 & 1 & \\
\hline (9) Seed yield & 0.29 & $-0.45^{*}$ & 0.33 & -0.21 & -0.21 & -0.23 & $0.58^{* *}$ & -0.08 & 1 \\
\hline
\end{tabular}

TABLE 4: Direct (along the diagonal) and indirect (above and below the diagonal) effects of yield components on seed yield.

\begin{tabular}{lcccccccc}
\hline Traits & 1 & 2 & 3 & 4 & 5 & 6 & 7 \\
\hline (1) Days to flowering & $0.40^{*}$ & 0.41 & 0.16 & -0.02 & 0.06 & 0.01 & 0.09 & -0.01 \\
(2) Duration of flowering & 0.30 & $-0.54^{* *}$ & -0.14 & 0.04 & -0.05 & 0.06 & -0.13 & -0.01 \\
(3) Days to maturity & -0.32 & 0.36 & 0.20 & 0.01 & 0.01 & -0.09 & 0.15 \\
(4) Plant height & 0.04 & -0.12 & 0.01 & 0.18 & -0.11 & -0.19 & -0.09 & 0.01 \\
(5) Number of branches & 0.08 & -0.09 & -0.01 & 0.06 & -0.29 & -0.19 & 0.13 & 0.05 \\
(6) Pods per main raceme & 0.01 & 0.07 & 0.04 & 0.08 & -0.14 & $-0.42^{*}$ & 0.02 & 0.11 \\
(7) Pods per plant & -0.06 & 0.12 & 0.05 & -0.03 & -0.07 & 0.02 & $0.58^{* *}$ & 0.01 \\
(8) Seeds per pod & 0.03 & 0.02 & 0.01 & 0.05 & 0.05 & 0.08 & 0.11 & 0.17 \\
\hline
\end{tabular}

${ }^{*, * *}$ Significant at $P<0.05$ and 0.01 , respectively.

TABLE 5: The results of stepwise regression analysis in which 3 out of 9 studied traits were selected.

\begin{tabular}{lcccc}
\hline Step & Variable entered & Partial $R$-square & Model $R$-square & $F$-test \\
\hline 1 & $X 7$ : pods per plant & 0.34 & 0.34 & $13.4^{* *}$ \\
2 & $X 5:$ number of branches & 0.12 & 0.46 & $5.7^{*}$ \\
3 & $X 2:$ duration of flowering & 0.07 & 0.56 & 3.3 \\
\hline \multicolumn{7}{r}{ Final regression model: $Y$ (seed yield) $=2835.9-16.4 X 7-269.6 X 5+22.5 X 7}$.
\end{tabular}

Final regression model: $Y$ (seed yield $)=2835.9-16.4 X 7-269.6 X 5+22.5 X 7$.

*,** Significant at $P<0.05$ and 0.01 , respectively.

advance for seed yield per plant, pods per plant, and seed weight in rapeseed (B. campestris) genotypes.

The results of stepwise regression analysis indicated that pods per plant, number of branches, and duration of flowering had considerable effects on seed yield (Table 5).

The results of factor analysis revealed three factors for the nine traits studied (Table 6). The eigenvalues for factors 1,2 , and 3 were $2.96,2.35$, and 1.33 , respectively. The cumulative variation for these factors was 0.74 while the proportion of variation contributed by each factor was $0.32,0.26$, and 0.15 , respectively. Factor 1 "could be regarded as the main factor (phenological traits)" and include days to flowering, duration of flowering, and days to maturity which had high coefficients on the factor loading. The second factor includes yield components such as number of branches, pods on main raceme, and seeds per pod. The third factor includes second yield components such as pods per plant and seed yield. In earlier studies $[15,18]$ factor analyses were used to determine structural factors related to growth trait and yield components and also for detecting factors relating to environmental stress including drought resistance in B. napus L.

In general, phenological traits, seeds per pod, and seed yield were more heritable than the other traits. Due to the significant positive correlation of yield components with seed yield these traits can be used as indirect selection criteria for improving seed yield. The low value of genetic coefficient of variation for days to maturity suggests that for improving this trait the correlated trait including days to flowering can be used as indirection selection criterion. 
TABLE 6: Factor analysis of all traits studied in rapeseed genotypes.

\begin{tabular}{lccc}
\hline Traits & \multicolumn{3}{c}{ Factor loadings } \\
& 1 & 2 & 3 \\
\hline (1) Days to flowering & $\mathbf{0 . 9 2}$ & -0.11 & 0.05 \\
(2) Duration of flowering & $-\mathbf{0 . 8 6}$ & 0.04 & -0.23 \\
(3) Days to maturity & $\mathbf{0 . 9 0}$ & 0.13 & 0.13 \\
(4) Plant height & -0.03 & 0.62 & -0.32 \\
(5) Number of branches & -0.23 & $\mathbf{0 . 7 9}$ & 0.19 \\
(6) Pods per main raceme & 0.18 & $\mathbf{0 . 8 3}$ & -0.13 \\
(7) Pods per plant & 0.09 & 0.13 & $\mathbf{0 . 9 1}$ \\
(8) Seeds per pod & 0.01 & $\mathbf{0 . 7 8}$ & 0.07 \\
(9) Seed yield & 0.31 & -0.23 & $\mathbf{0 . 7 7}$ \\
\hline Eigen value & 2.96 & 2.35 & 1.33 \\
\hline Portion & 0.32 & 0.26 & 0.15 \\
\hline Cumulative & 0.32 & 0.59 & 0.74 \\
\hline
\end{tabular}

\section{Conflict of Interests}

The author declares that there is no conflict of interests regarding the publication of this paper.

\section{Acknowledgments}

The author wishes to thank Agricultural and Natural Resources Research Center of Mazandaran and Seed and Plant Improvement Institute (SPII) for providing genetic materials and facility for conducting this experiment.

\section{References}

[1] G. G. Khachatourians, A. K. Summer, and P. W. B. Phillips, An Introduction to the History of Canola and the Scientific Basis for Innovation, CABI, London, UK, 2001.

[2] M. J. Mahasi and J. W. Kamundia, "Cluster analysis in rapeseed (Brassica napus L.)," African Journal of Agricultural Research, vol. 2, no. 9, pp. 409-411, 2007.

[3] Z. Aytac, G. Kinaci, and E. Kinaci, "Genetic variation, heritability and path analysis of summer rapeseed cultivars," Journal of Applied and Biological Science, vol. 2, no. 3, pp. 35-39, 2008.

[4] M.-J. Ana, K.-S. Ankica, S. Dejana, M. Radovan, and H. Nikola, "Phenotypic and molecular evaluation of genetic diversity of rapeseed (Brassica napus L.) genotypes," African Journal of Biotechnology, vol. 8, no. 19, pp. 4835-4844, 2009.

[5] I. Ofori, "Correlation and path-coefficient analysis of components of seed yield in bambara groundnut (Vigna subterranea)," Euphytica, vol. 91, no. 1, pp. 103-107, 1996.

[6] B. R. Choudhary and P. Joshi, "Genetic diversity in advanced derivatives of Brassica interspecific hybrids," Euphytica, vol.121, no. 1, pp. 1-7, 2001.

[7] A. A. Leilah and S. A. Al-Khateeb, "Yield analysis of canola (Brassica napus L.) using some statistical procedures," Saudi Journal of Biological Sciences, no. 12, pp. 103-113, 2005.

[8] Z. Aytaç and G. Kinaci, "Genetic variability and association studies of some quantitative characters in winter rapeseed (Brassica napus L.)," African Journal of Biotechnology, vol. 8, no. 15, pp. 3547-3554, 2009.
[9] F. A. Khan, S. Ali, A. Shakeel, A. Saeed, and G. Abbas, "Correlation analysis of some quantitative characters in Brassica napus L.," Journal of Agricultural Research, no. 44, pp. 7-14, 2006.

[10] S. Ivanovska, C. Stojkovski, Z. Dimov, A. Marjanovic-Jeromela, M. Jankulovska, and L. J. Jankuloski, "Interrelationship between yield and yield related traits of spring canola (Brassica napus L.) genotypes," Genetika, vol. 39, pp. 325-332, 2007.

[11] D. Basalma, "The correlation and path analysis of yield and yield components of different winter rapeseed (Brassica napus ssp. oleifera L.) cultivars," Research Journal of Agriculture and Biological Sciences, vol. 4, pp. 120-125, 2008.

[12] H. A. Sadat, G. Ali Nematzadeh, N. B. Jelodar, and O. G. Chapi, "Genetic evaluation of yield and yield components at advanced generations in rapeseed (Brassica napus L.)," African Journal of Agricultural Research, vol. 5, no. 15, pp. 1958-1964, 2010.

[13] Y. Semahegn Belete, "Genetic variability, correlation and path analysis studies in Ethiopian mustard (Brassica carinata A. Brun) genotypes," International Journal of Plant Breeding and Genetics, vol. 5, no. 4, pp. 328-338, 2011.

[14] S. Sharma, Applied Multivariate Techniques, John Wiley \& Sons, New York, NY, USA, 1st edition, 1996.

[15] R. Naderi and Y. Emam, "Interrelationships among grain yield and related characters of four oilseed rape (Brassica napus L.) cultivars under drought stress conditions," Desert, vol. 15, no. 2, pp. 133-138, 2010.

[16] M. Singh, S. Ceccarelli, and J. Hamblin, "Estimation of heritability from varietal trials data," Theoretical and Applied Genetics, vol. 86, no. 4, pp. 437-441, 1993.

[17] S. Khan, I. Farhatullah, and H. Khallil, "Phenotypic correlation analysis of elite F3:4 Brassica populations for quantitative and qualitative traits," ARPN, Journal of Agriculture and Biological Sciences, no. 3, pp. 38-42, 2008.

[18] V. Rameeh, "Combining ability and factor analysis in $\mathrm{F}_{2}$ diallel crosses of rapeseed varieties," Plant Breeding and Seed Science, vol. 62, pp. 73-83, 2010.

[19] SAS Institute Inc, SAS/STAT User's Guide, Version 9, Statistical Analysis Institute Inc., Cary, NC, USA, 4th edition, 2004.

[20] N. Sabaghnia, H. Dehghani, B. Alizadeh, and M. Mohghaddam, "Interrelationships between seed yield and 20 related traits of 49 canola (Brassica napus L.) genotypes in non-stressed and water-stressed environments," Spanish Journal of Agricultural Research, vol. 8, no. 2, pp. 356-370, 2010.

[21] A. Marjanović-Jeromela, R. Marinković, A. Mijić, M. Jankulovska, and Z. Zdunić, "Interrelationship between oil yield and other quantitative traits in rapeseed (Brassica napus L.)," Journal of Central European Agriculture, vol. 8, no. 2, pp. 165-170, 2007.

[22] F. A. Sheikh, A. G. Rather, and S. A. Wani, "Genetic variability and inter-relationship in toria Brassica campestris L. var. toria," Advances in Plant Sciences, vol. 12, no. 1, pp. 139-143, 1999. 


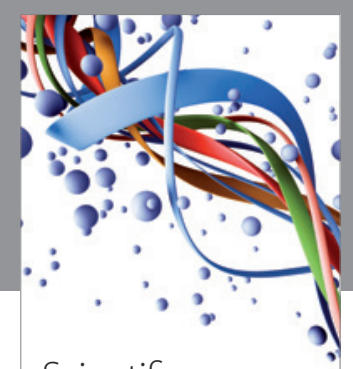

Scientifica
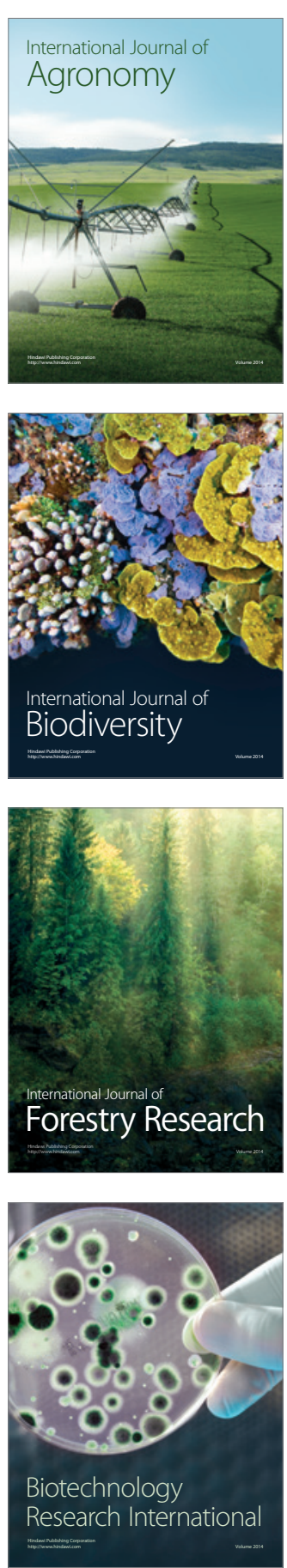
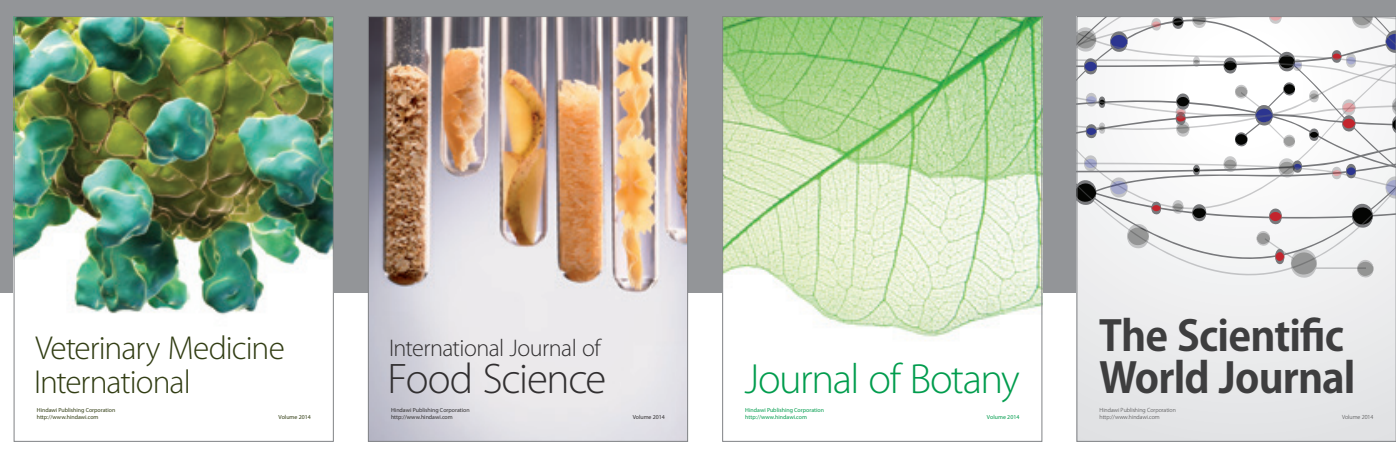

The Scientific World Journal
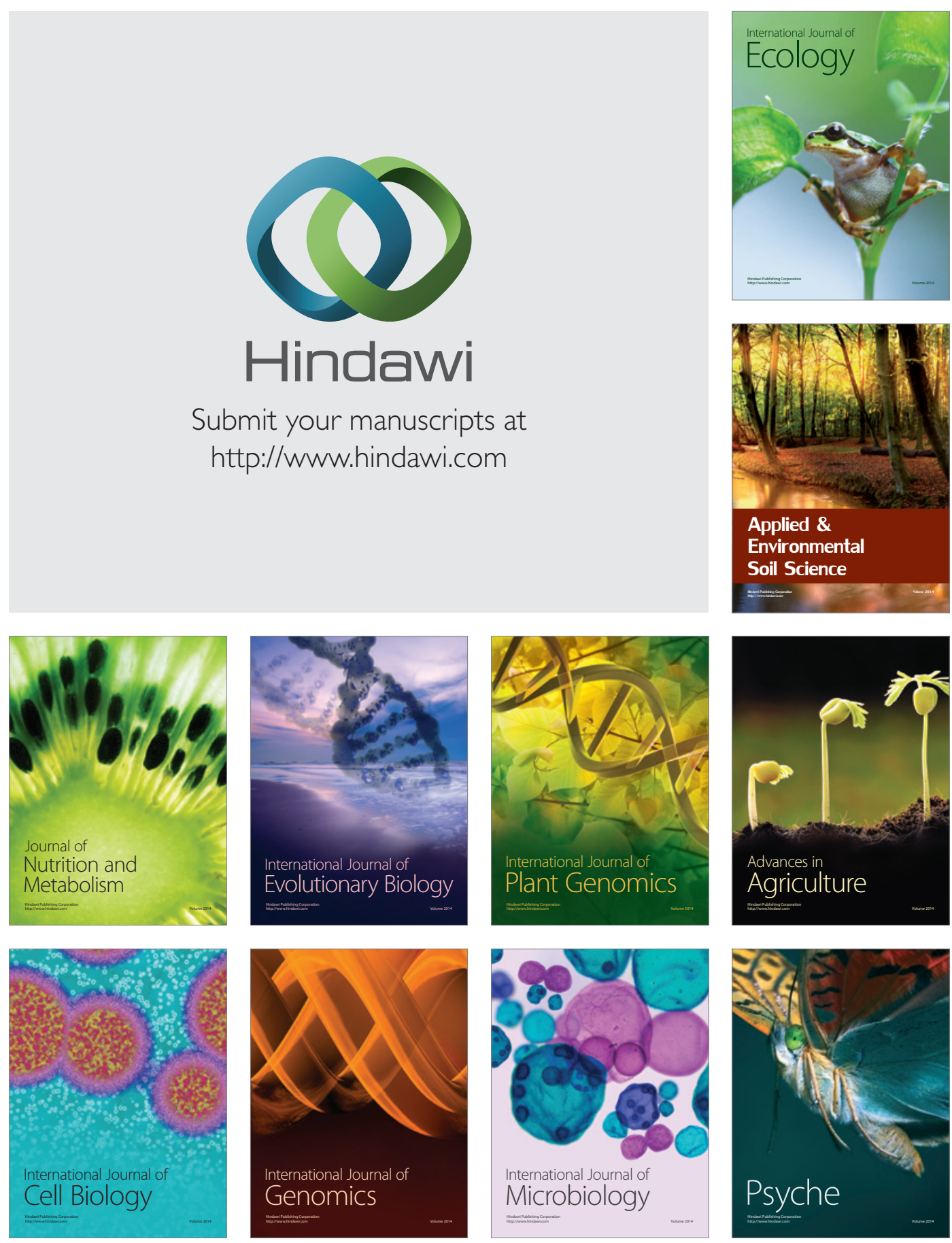